\title{
An overview of Listeria monocytogenes contamination in ready to eat meat, dairy and fishery foods
}

\author{
Carla Susana Rodrigues ${ }^{1}$ Cláudia Valéria Gonçalves Cordeiro de Sá $^{2}$ \\ Cristiano Barros de Melo ${ }^{1 *, 2}$
}

${ }^{1}$ Laboratório de Doenças Infecciosas de Notificação Obrigatória (UnB/FAV/DINO), Universidade de Brasília (UnB), Campus Darcy Ribeiro, ICC Sul, 70910-900, Asa Norte, Brasília, DF, Brasil. E-mail: cristianomelo@unb.br. "Corresponding author.

${ }^{2}$ Secretaria de Defesa Agropecuária (SDA), Departamento de Inspeção de Produtos de Origem Animal (DIPOA), Ministério da Agricultura Pecuária e Abastecimento (MAPA), Esplanada dos Ministérios, Brasília, DF, Brasil.

\begin{abstract}
Listeria monocytogenes is a relevant foodborne pathogen in public health, responsible for outbreaks of listeriosis often associated to the consumption of ready to eat meat, dairy and fishery products. Listeriosis is a serious disease that can lead to death and mainly affect children, the elderly and immunocompromised individuals. In pregnant women causes abortion or neonatal listeriosis. In Brazil, ready to eat food are appreciated and increasingly consumed by the population. Furthermore, products such as sausages, bologna, hams and cheeses have characteristics such as pH, Aw and sodium chloride content that favor the development of $\boldsymbol{L}$. monocytogenes during their shelf life. The purpose of this paper was to present an overview of $\boldsymbol{L}$. monocytogenes contamination in different meat, dairy and fishery products that are ready for consumption and thereby support the adoption of strategies to mitigate this risk, contributing to achieve the appropriate level protection for the consumers and thus strengthen Brazil's food safety system. Key words: Food safety, ready to eat, contamination, listeriosis.
\end{abstract}

Uma visão geral sobre contaminação por Listeria monocytogenes em alimentos cárneos, laticícios e pescado prontos para o consumo

RESUMO: Listeria monocytogenes é um patógeno de importância em saúde pública por estar associado a surtos de listeriose, muitas vezes causados por produtos de origem animal prontos para o consumo. Listeriose é uma doença grave que pode levar ao óbito crianças, idosos e indivíduos imunocomprometidos. Em gestantes ocasiona aborto ou listeriose neonatal. No Brasil, os produtos de origem animal, prontos para consumo, são cada vez mais apreciados pela população. Eles, muitas vezes, podem ser ingeridos sem a necessidade de que o consumidor realize preparo prévio do alimento por meio de calor. Além disso, produtos como salsicha, mortadela, presunto e queijo possuem características como pH, Aw e teor de cloreto de sódio que favorecem o desenvolvimento de L. monocytogenes ao longo da vida de prateleira. Objetivou-se com este trabalho apresentar um panorama da contaminação por L. monocytogenes em produtos cárneos, lácteos e pescados prontos para consumo e, assim, auxiliar na adoção de estratégias para mitigar o risco, contribuindo para alcançar um nivel adequado de proteção do consumidor e fortalecer o sistema de segurança alimentar brasileiro. Palavras-chave: Segurança alimentar, alimentos prontos para consumo, contaminação, listeriose.

\section{INTRODUCTION}

Listeriosis has been recognized in the 1920 s as an infection caused by a Gram positive bacterium later called Listeria monocytogenes. In 1981, an outbreak in Canada was first associated with the presence of this pathogen in foods, encouraging the development of research on the ubiquitous features of the microrganism and its pathogenicity (TODD \& NOTERMANS, 2011). Since then, it is considered an important bacterium in public health, responsible for foodborne disease that despite the low incidence, has a high mortality rate among affected individuals (CARTWRIGHT et al., 2013; COSSART \& LEBRETON, 2014; NOORDHOUT et al., 2014).
Ready to eat foods are those that do not require preparation by heat employment before being ingested by the consumer, and mostly those made from meat, dairy products and smoked fish were most often related to listeriosis outbreaks in Canada, European Union and United States, countries where the notification of this disease is compulsory (MCLAUCHLIN et al., 2004; FARBER et al., 2011; TODD \& NOTERMANS, 2011; CARTWRIGHT et al., 2013).

Despite the efforts that have been made by food industries and sanitary authorities, listeriosis outbreaks are still being notified in Europe and Unites States and it is possible that it tends to rise as the number of individuals elderly and immunocompromised increases, as well as pregnant women and children, 
are more susceptible to this disease (SLUTSKER et al., 1998; GANDHI \& CHIKINDAS, 2007; CRUZ et al., 2008). In Brazil, in the year 2013 people over 65 years old represented $7.6 \%$ of the population and has been estimated that by the year 2060 this group will represent $26.8 \%$ (IBGE, 2013). So with population getting older and observed changes in eating habits with an increased consumption of food ready for consumption, it is possible that in the coming years listeriosis become increasingly relevant in terms of public health. It would be important to include listeriosis as a compulsory notifiable disease in Brazil, being indispensable a proper diagnosis of listeriosis and investigation to identify the implicated food.

According to Food and Agricultural Organization (FAO) guidelines (DUBUGRAS \& PÉREZ-GUTIERREZ, 2008), a modern food safety system is proactive and based on risk. Therefore, it is necessary to identify the diseases that affect the population and the presence of pathogens in food to then establish risk mitigation measures. This paper aimed to present an overview of $L$. monocytogenes contamination in different meat, fishery and dairy products ready to eat and; thus draw attention to the importance of studies to identify the presence of pathogens in food produced in Brazil, under national conditions. Such information will help to strengthen Brazil's food safety system.

\section{Listeria monocytogenes}

Listeria monocytogenes is a Gram positive bacteria, anaerobic facultative, nonsporeforming, facultative intracellular able to grow in temperatures between 0 and $45^{\circ} \mathrm{C}$, that supports $\mathrm{pH}$ between 4,4 and 9,4 and requires minimum water activity of $0,92(\mathrm{WHO} /$ FAO, 2004). Based on somatic and flagellar antigens $\boldsymbol{L}$. monocytogenes has 13 serotypes $1 / 2 \mathrm{a}, 1 / 2 \mathrm{~b}, 1 / 2 \mathrm{c}, 3 \mathrm{a}$, $3 \mathrm{~b}, 3 \mathrm{c}, 4 \mathrm{a}, 4 \mathrm{ab}, 4 \mathrm{~b}, 4 \mathrm{c}, 4 \mathrm{~d}, 4 \mathrm{e}$ and three of them (1/2a, $1 / 2 b, 4 b)$ are more frequently related to human listeriosis (CLARK et al., 2010; FDA, 2012; CARTWRIGHT et al., 2013; PÉREZ-TRALLERO et al., 2014).

This bacterium has the ability to survive and multiply under low temperature and it is able to persist for long periods in soil, water, feed and animal feces, being easily detected in the environment (TIWERI et al., 2014). Animal contamination can occur by consumption of water, pasture or silage and the presence of $\boldsymbol{L}$. monocytogenes in fecal excretion was not necessarily related to the occurrence of listeriosis (CZUPRYNSKI, 2005; ESTEBAN et al., 2009).

In food processing plants the microrganism may remain from months to years due to its ability to form biofilm, being detected by laboratory tests even after sanitization (TODD \& NOTERMANS, 2011;
MENDONÇA et al., 2012; CASELANI et al., 2013; HENRIQUES et al., 2014).

\section{Human listeriosis}

Listeriosis is an infectious disease that causes abortion, meningitis and septicemia, affecting mainly pregnant women, newborn children, adults over 65 years old and individuals with compromised immune systems, including those with cancer, diabetes, HIV positive, liver diseases and immunosuppressive drug users as patients undergoing organ transplants. Despite its low incidence, the clinical conditional is severe and the mortality rate is high, ranging between $15 \%$ and $30 \%$ of affected individuals (MCLAUCHLIN, 1997; WHO/FAO, 2004; CRUZ et al., 2008; TODD \& NOTERMANS, 2011; CDC, 2013a; COSSART \& LEBRETON, 2014).

In the $80 \mathrm{~s}$, due to the increase in the number of cases, listeriosis has been recognized as an important foodborne disease. In 1981, a listeriosis outbreak in Canada was for the first time associated to the consumption of coleslaw and resulted in 17 deaths. In 1983, the first listeriosis outbreak occurred in the United States involving the ingestion of raw milk. In the United States, between 1998 and 2008, were confirmed 24 listeriosis outbreaks attributed to delicatessen (deli) meats, frankfurters and Mexican style cheese made from pasteurized and unpasteurized milk. The largest outbreak occurred in 1998 and was associated with the consumption of frankfurter resulting in 14 deaths (FARBER et al., 2011; CARTWRIGHT et al., 2013). In this country, $\boldsymbol{L}$. monocytogenes was appointed as the third leading cause of death by foodborne disease (SCALLAN et al., 2011).

In the European Union, in 2013 year, were registered 1,743 cases of listeriosis with $15.6 \%$ mortality (EFSA, 2015). In most EU member countries, in the United States, Canada and Australia listeriosis rate was approximately 0.3 cases per 100,000 individuals (TODD \& NOTERMANS, 2011; CDC, 2015). This rate was 1.3 in Iceland, 1.6 in Denmark, 1.0 in Norway and 0.6 in Sweden, possibly because in those countries there is a high consumption of smoked fish (TODD \& NOTERMANS, 2011; ANONYMOUS, 2015). In New Zealand listeriosis rate was 0.6 cases per 100,000 individuals (CRERAR et al., 2011).

In a meta-analysis studied conducted by NOORDHOUT et al. (2014), it was estimated that only in 2010, about 23,150 people were stricken by listeriosis in the world, resulting in 5,463 deaths. Most reported listeriosis outbreaks occurred in Europe, Canada, United States and, in lesser extent, in Australia and New Zealand (TODD \& NOTERMANS, 2011). Although L. monocytogenes can be reported in a wide variety of food, outbreaks and sporadic cases in humans are 
predominantly related to the consumption of ready to eat food (OKUTANI et al., 2004; WHO/FAO, 2004; TODD \& NOTERMANS, 2011; LAMBERTZ et al., 2012).

In 2008, an outbreak in Canada involving meat products was responsible for the death of 23 people. This episode prompted health authorities to review public policies for $\boldsymbol{L}$. monocytogenes in food control (FARBER et al., 2011; TODD \& NOTERMANS, 2011).

In Brazil, epidemiological surveillance of foodborne diseases is conducted according to the protocols defined by Ministry of Health (BRASIL, 2010). Between 2000 and 2015 years (data until May/15) 10,666 outbreaks of foodborne diseases have been officially reported, with 209,240 patients and 154 deaths. Of all these outbreaks, approximately $20.2 \%$ were associated with eggs and products containing eggs, milk and dairy products, beef, pork and poultry fresh, processed and viscera, fish, seafood and fishery products. Among the foodborne outbreaks that the etiologic agent have been identified (about 41.9\%), none of them was related to $L$. monocytogenes (BRASIL, 2015). In contrast with United States and European data, it demonstrated that the occurrence of this disease in Brazil is not well known.

However, considering the fact that reports about this microrganism detection in different foods marketed in the country are frequently (PETTINATI et al., 2006; ROSSI et al., 2011; FAI et al., 2011; MENDONÇA et. al., 2012; ANDRADE et al., 2014; RISTORI et al., 2014) as well as its isolation in hospitalized patients, but without associating with the consumption of a particular food (CRUZ et al., 2008; MARTINS et al., 2010; REIS et al., 2011), it can be inferred that there is a possibility of non notification of listeriosis human cases in Brazil. So, despite these reports, there is not enough data about the occurrence of the disease in population and implied food.

\section{Listeria monocytogenes in ready to eat meat, dairy and fishery foods \\ Contaminated food with $L$. monocytogenes} represents the main source of listeriosis transmission to humans. From the gastrointestinal tract the pathogen might cause a non-invasively localized infection in the intestine or an invasive infection, which may be systemic or localized (CRUZ et al., 2008). The likelihood of invasion from the gastrointestinal tract depends on several factors, including the number of ingested bacteria cells, the susceptibility of the host and the virulence of the strain (HOF \& ROCOURT, 1992; WHO/FAO, 2004).

Among foods, those that are ready to eat, so that did not require a heat preparation before being ingested by the consumer, mainly those food prepared from meat, dairy products and smoked fish, were more often related to listeriosis outbreak in countries where the notification of this disease is compulsory (MCLAUCHLIN et al., 2004; TODD \& NOTERMANS, 2011; CARTWRIGHT et al., 2013).

Hygienic failing during slaughter allow contamination of meat and industrial facilities with animal feces. In addition, failures in compliance with good manufacturing and hygiene practices allow the bacterium to be carried into the industry by shoes, clothing, transport equipment and people. In industrial facilities $\boldsymbol{L}$. monocytogenes can be reported in drains, mats, coolers, air filters, walls, cleaning utensils and other environments that are wet, cold and difficult to clean, where it can survive for long periods due to its ability to form biofilms and resist to bacterial agents that causes bacterium stresses (CZUPRYNSKI, 2005; GANDHI \& CHIKINDAS, 2007; CESAR et al., 2011; LEONG et al., 2014).

Biofilms formed by Listeria spp. are a special concern in the food industry, once they confer to the bacterium a greater resistance to disinfectants and sanitizers and represent a medium of contamination for the products being manipulated after the lethality heat treatment (GANDHI \& CHIKINDAS, 2007; MARTÍN et al., 2014). The presence of $\boldsymbol{L}$. monocytogenes in the industrial processing environment represents a risk to the food products due to cross contamination. Research conducted by MUHTEREM-UYAR et al. (2015) indicated that the presence of $\boldsymbol{L}$. monocytogenes is higher in meat processing establishments than in dairy industries, possibly because of the most probability of spread contamination from dirty areas, as bleeding and evisceration, to the clean areas, as boning and packaging. In the European Union, between 2010 and 2011, a baseline survey was carried out to estimate L. monocytogenes prevalence in ready to eat (RTE) foods. In fishery food was reported $10.4 \%$ of samples positive for $\boldsymbol{L}$. monocytogenes. In RTE meat food was observed that this pathogen was presented in $2.07 \%$ of analyzed samples and in $0.47 \%$ of cheese samples, both products samples were examined at the end of product shelf life (EFSA, 2013).

In Sweden, 2010, the National Food Agency (NFA) examined the presence of $\boldsymbol{L}$. monocytogenes in RTE foods and detected this pathogen in $12 \%$ of fish samples, $1.2 \%$ of meat product samples and $0.4 \%$ in cheese samples (LAMBERTZ et al., 2012). In Estonian, a survey baseline conducted in 2008-2010, identified L. monocytogenes in $18.7 \%$ of raw meat and raw meat products, $2 \%$ in RTE meat products and $0.3 \%$ in RTE milk products (KRAMARENKO etal., 2013). In Ireland, RTE food samples were examined between March 
2013 and March 2014 showing L. monocytogenes contamination in $3.2 \%$ of dairy products and $4.2 \%$ of meat products (LEONG et al., 2014). In Denmark, 2014, L. monocytogenes was identified in $2.32 \%$ of RTE meat products and in $8.45 \%$ of RTE fish and fishery products, the pathogen was not detected in cheese, milk and other RTE dairy products (ANONYMOUS, 2015).

In the United States, in 2008, 959 samples of RTE meat products were examined, and in $5(0.52 \%)$ were reported $L$. monocytogenes, of these, 2 were from frankfurters (MAMBER, 2010). In Australia, data from 1997 to 2003 appointed $L$. monocytogenes contamination rate in $4.7 \%$ of sliced RTE meat products, $1.2 \%$ in pates and $2.7 \%$ in cooked sausages and frankfurters (ROSS et. al., 2009). In Chile, samples examined between 2008 and 2012 detected $\boldsymbol{L}$. monocytogenes in 5\% of sausage and cured meat, 3\% in cheese and 3\% in seafood (SALUDES et al., 2015). In table 1 is given $L$. monocytogenes contamination in different food per country.

\section{The role of oficial service in food safety}

In industries, the microbiological food safety is achieved by strict control of the raw material origin, the use of food additives which contribute to the formation of barriers to the pathogen development, adequate cooking with time and temperature for disposal of viable bacterial cells (lethality heat treatment) and maintain adequate hygienic conditions of the process, particularly product handling after heat treatment.

Risk analysis in food has become even more important with the development of new models of production and processing, with the changes in food consumption patterns and expansion of international trade, which contributed to the emergence of new hazards to which the population is exposed. So, increasingly, it is necessary to establish rules and standards for the production and trade of safe food and quality (DUBUGRAS \& PÉREZ-GUTIERREZ, 2008).

In 2007, Codex Alimentarius Commission published guidelines on the application of general principles of food hygiene to the control of $\boldsymbol{L}$. monocytogenes in foods (CAC, 2009). Whereas productsready forconsumption with high contamination of $\boldsymbol{L}$. monocytogenes are the ones that represent higher risk for listeriosis and control measures aim to prevent contamination and development of pathogens in food, from primary production to consumption chain. Such measures should be implemented through strict fulfillment of good manufacturing practices (GMP) and sanitation operating procedures (SSOP), supporting an effective plan of Hazard Analysis and Critical Control Points (HACCP) for pathogen control.
In the United States was adopted a zero tolerance policy for ready to eat food, it means that detecting 1CFU of L. monocytogenes in $25 \mathrm{~g}$ of sample implies in recall of the contaminated product and interruption of the producer activities until the contamination problem is solved (ORSI et al., 2011).

In Canada, after a foodborne outbreak in 2008, the Canadian Inspection Agency (CFIA) has developed new guidelines for $\boldsymbol{L}$. monocytogenes control in industries producing RTE meat products, including a contact surface monitoring program which involves compulsory communication about positive results for Listeria spp. and L. monocytogenes observed during the execution of environmental monitoring as part of the HACCP program in every food establishment. In addition, health authorities, along with the food producers, began to work together in order to minimize exposure to $\boldsymbol{L}$. monocytogenes, including the distribuition of educational material for consumers (FARBER et al., 2011).

In Europe, Regulation 2073/2005 lays down microbiological criteria applicable to all RTE food. For products with a shelf life of less than five days or intrinsic factors justifying the absence of pathogen growth, it adopted tolerance of 100CFU of $\boldsymbol{L}$. monocytogenes per gram of product, assuming that this number will not increase during its shelf life. For other products it is adopted absence in 25 grams. It is also carried out analyzes of contact surfaces with food in order to monitor the efficiency of HACCP plan (DUFOUR, 2011).

In Brazil, the Ministry of Agriculture Livestock and Food Supply (MAPA) established the procedures for the control of $\boldsymbol{L}$. monocytogenes in animal products ready for consumption that have a $\mathrm{pH}$ greater than 4.4 , water activity greater than 0.92 and concentration sodium chloride less than $10 \%$, i.e., having favorable characteristics for microorganism growth. The criterion adopted is the absence of $\boldsymbol{L}$. monocytogenes in 25g (BRASIL, 2009). Cooked and smoked hams, bologna, cooked sausages, cooked and smoked sirloin and palette, soft and semi soft cheese, smoked fish, surimi, cooked and frozen bivalve mollusk and shrimp are officially monitored by a national sampling plan in industries under federal inspection (BRASIL, 2013). Besides that, the Federal Inspection Service (SIF) monitors the industries to check the use of appropriate tools aiming to ensure the safety of meat, dairy and fishery products, such as GMP, SSOP and HACCP.

Risk analysis is recommended by $\mathrm{FAO} /$ WHO to strengthen food safety systems and it supports decision-making related to food safety. Baseline survey is a way to obtain data to estimate the national prevalence of $\boldsymbol{L}$. monocytogenes in food, and is one of the risk assessment components that can contribute to the choice of control measures alternatives as part of a public policy 
Table 1 - Listeria monocytogenes contamination in different foods per country.

\begin{tabular}{|c|c|c|c|c|}
\hline Country & Survey period & Food product & L. monocytogenes contamination & Reference \\
\hline \multirow{3}{*}{ EU } & \multirow{3}{*}{2010 to 2011} & Fishery food & $10.4 \%$ & \multirow{3}{*}{ EFSA (2013) } \\
\hline & & RTE meat food & $2.07 \%$ & \\
\hline & & Cheese & $0.47 \%$ & \\
\hline \multirow{2}{*}{ Ireland } & \multirow{2}{*}{2013 to 2014} & Dairy products & $3.2 \%$ & \multirow{2}{*}{$\begin{array}{l}\text { LEONG et al. } \\
(2014)\end{array}$} \\
\hline & & Meat products & $4.2 \%$ & \\
\hline \multirow{3}{*}{ Sweden } & \multirow{3}{*}{2010} & Fish & $12 \%$ & \multirow{3}{*}{$\begin{array}{l}\text { LAMBERTZ et } \\
\text { al. (2012) }\end{array}$} \\
\hline & & Meat products & $1.2 \%$ & \\
\hline & & Cheese & $0.4 \%$ & \\
\hline \multirow{3}{*}{ Estonian } & \multirow{3}{*}{2008 to 2010} & Raw meat and raw meat products & $18.7 \%$ & \multirow{3}{*}{$\begin{array}{l}\text { KRAMARENKO } \\
\text { et al. (2013) }\end{array}$} \\
\hline & & RTE meat product & $2 \%$ & \\
\hline & & RTE milk product & $0.3 \%$ & \\
\hline \multirow{3}{*}{ Denmark } & \multirow{3}{*}{2014} & RTE milk product & $2.32 \%$ & \multirow{3}{*}{$\begin{array}{l}\text { ANONYMOUS, } \\
(2015)\end{array}$} \\
\hline & & Fish and fishery products, RTE & $8.45 \%$ & \\
\hline & & Cheese, milk and dairy products, RTE & 0 & \\
\hline United States & 2008 & RTE meat products & $0.52 \%$ & $\begin{array}{l}\text { MAMBER, } \\
(2010)\end{array}$ \\
\hline \multirow{3}{*}{ Australia } & \multirow{3}{*}{1997 to 2003} & Sliced RTE meat products & $4.7 \%$ & \multirow{3}{*}{$\begin{array}{l}\text { ROSS et al., } \\
(2009)\end{array}$, } \\
\hline & & Pates & $1.2 \%$ & \\
\hline & & Frankfurters & $2.7 \%$ & \\
\hline \multirow{3}{*}{ Chile } & \multirow{3}{*}{2008 to 2012} & Sausages and cured meat & $5 \%$ & \multirow{3}{*}{$\begin{array}{l}\text { SALUDES et al., } \\
(2015)\end{array}$} \\
\hline & & Cheese & $3 \%$ & \\
\hline & & Seafood & $3 \%$ & \\
\hline
\end{tabular}

that aims to offer safe food for consumers (OPAS/WHO, 2009). Those data from official monitoring of ready to eat meat, cheese and fishery products could be useful to achieve $\mathrm{FAO} / \mathrm{WHO}$ recommendation.

\section{CONCLUSION}

Baseline surveys to estimate the national prevalence of $\boldsymbol{L}$. monocytogenes in animal products ready for consumption, obtained under Brazilian production conditions, is essential to support the risk assessment and contribute to the adoption of strategies that aim to achieve an adequate level of protection (ALOP) for the consumer and food safety objectives (FSO) established by the inspection service respecting food production conditions in Brazil.

\section{ACKNOWLEDGEMENTS}

The authors are grateful to MAPA (authorizations - CS Rodrigues and CVGC de Sá) and to Conselho Nacional de Desenvolvimento Científico e Tecnológico (CNPq), by the productivity scholarship (CB de Melo).

\section{REFERENCES}

ANDRADE, R.R. et al. Occurrence and differentiation of Listeria spp. in "hot dog" sausages sold in bulk and ground beef samples marketed in the Federal District, Brazil. Ciência Rural, v.44, p.147-152, 2014. Avaliable from: <http://www.scielo.br/scielo.php?script=sci_arttext \&pid=S0103-84782014000100024>. Accessed: May 22, 2016. doi: 10.1590/S0103-84782014000100024.

ANONYMOUS. Annual report on zoonoses in Denmark 2015, National Food Institute. Technical University of Denmark. Avaliable from: $<$ file://C:/Users/pc/Downloads/Annual\%20Report $\% 202014 \% 20$ final.pdf $>$. Accessed: May 22, 2016.

BRASIL. Ministério da Agricultura, Pecuária e Abastecimento. Instrução Normativa n. 9, de 8 de abril de 2009. Institui os procedimentos de controle da Listeria monocytogenes em produtos de origem animal. Diário Oficial da União, 2009.

BRASIL. Ministério da Agricultura, Pecuária e Abastecimento. Norma Interna DIPOA/SDA n. 1, de 9 de agosto de 2013. Aprova os procedimentos operacionais complementares à Instrução Normativa n. 9, de 8 de abril de 2009, definindo os procedimentos para a coleta oficial de amostras para o controle de Listeria monocytogenes em produtos de origem animal prontos para o consumo a serem adotados pelo Serviço de Inspeção Federal. Boletim de Pessoal, 2013. 
BRASIL. Ministério da Saúde. Secretaria de Vigilância em Saúde. Departamento de Vigilância Epidemiológica. Manual integrado de vigilância, prevenção e controle de doenças transmitidas por alimentos. Brasília: Editora do Ministério da Saúde, 2010.

BRASIL. Ministério da Saúde. Doenças transmitidas por alimentos. Brasília: MS, 2015. Avaliable from: <http://u.saude.gov.br/images/ pdf/2015/novembro/09/Apresenta----o-dados-gerais-DTA-2015.pdf $>$. Accessed: October 04, 2016

CODEX ALIMENTARIUS COMISSION (CAC). Guidelines on the application of general principles of food hygiene to the control of Listeria monocytogenes in ready-to-eat foods. CAC/ GL 61-2007. Roma: FAO, 2009. 28p.

CARTWRIGHT, E.J. et al. Listeriosis outbreaks and associated food vehicles, United States, 1998-2008. Emerging Infectious Diseases, v.19, p.1-9, 2013. Avaliable from: <http://wwwnc.cdc.gov/eid/ article/19/1/12-0393_intro>. Accessed: May 22, 2016.

CASELANI, K. et al. Ocorrência de Listeria spp. e de Listeria monocytogenes em um matadouro frigorífico de bovinos no Estado de São Paulo. Bioscience Journal, v.29, p.956-961, 2013. Avaliable from: <http://www.seer.ufu.br/index.php/biosciencejournal/article view/17284>. Accessed: May 22, 2016

CENTERS FOR DISEASE CONTROLAND PREVENTION(CDC). Surveillance system overview: the Listeria initiative. Avaliable from: $<\mathrm{http} / / /$ www.cdc.gov/listeria/pdf/ListeriaInitiativeOverview_508. pdf $>$. Accessed: May 22, 2016

CENTERS FOR DISEASE CONTROL AND PREVENTION (CDC). Listeria (Listeriosis) Statistics. Avaliable from: $<$ http://www. cdc.gov/listeria/statistics.html>. Accessed: May 22, 2016.

CESAR, A.P.R. et al. Listeria spp. e Listeria monocytogenes na produção de salsichas tipo hot dog. Ciencia Animal Brasileira, v.12, p.339-352, 2011. Avaliable from: <https://revistas.ufg.emnuvens. com.br/vet/article/view/7452/9261>. Accessed: May 22, 2016.

CLARK, C.G. et al. Surveillance for Listeria monocytogenes and listeriosis, 1995-2004. Epidemiology and Infection, v.138, p.559-572, 2010. Avaliable from: $<$ http://journals.cambridge.org/action/displayAbs tract?fromPage $=$ online \&aid $=7286060 \&$ fileId $=$ S0950268809990914 $>$. Accessed: May 22, 2016. doi: 10.1017/S0950268809990914.

COSSART, P.; LEBRETON, A. A trip in the "New Microbiology" with the bacterial pathogen Listeria monocytogenes. Federation of European Biochemical Societies, v.588, p.2437-2445, 2014. Avaliable from: $<$ http://onlinelibrary.wiley.com/doi/10.1016/j.febslet.2014.05.051/full>. Accessed: May 22, 2016. doi: 10.1016/j.febslet.2014.05.051.

CRERAR, S.K. et al. Recent experiences with Listeria monocytogenes in New Zealand and development of food control risk-base strategy. Food Control, v.22, p.1510-1512, 2011. Avaliable from: $<$ http://www.sciencedirect.com/science/article/pii/ S0956713510002379>. Accessed: May 22, 2016. doi: 10.1016/j. foodcont.2010.07.016.

CRUZ, C.D. et al. Listeria monocytogenes: um agente infeccioso ainda pouco conhecido no Brasil. Alimentos e Nutrição, v.19, p.195206, 2008. Avaliable from: $<$ http://serv-bib.fcfar.unesp.br/seer/index. php/alimentos/article/viewFile/247/241>. Accessed: May 22, 2016.

CZUPRYNSKI, C.J. Listeria monocytogenes: silage, sandwiches and science. Animal Health Research Reviews, v.6, p.211-217, 2005.
Avaliable from: <http://journals.cambridge.org/action/displayAbstr act? fromPage $=$ online \& $\mathrm{aid}=916836 \&$ fileId $=\mathrm{S} 1466252305000137>$. Accessed: May 22, 2016. doi: 10.1079/AHR2005111.

DUBUGRAS, M.T.B.; PÉREZ-GUTIERREZ, E. Perspectiva sobre a análise de risco na segurança dos alimentos. Curso de sensibilização. Rio de Janeiro: Área de Vigilância Sanitária, Prevenção e Controle de Doenças - OPAS/OMS, 2008. 160p. Avaliable from: <http://bvs.panalimentos.org/local/File/Apostila Final_12_08_2008.pdf $>$. Accessed: May 22, 2016.

DUFOUR, C. Application of EC regulation no 2073/2005 regarding Listeria monocytogenes in read-to-eat foods in retail and catering sectors in Europe. Food Control, v. 22, p.1491-1494, 2011. Avaliable from: <http://www.sciencedirect.com/science/article/pii/ S0956713510002331>. Accessed: May 22, 2016. doi: 10.1016/j. foodcont.2010.07.012.

ESTEBAN, J.I. et al. Faecal shedding and strain diversity of Listeria monocytogenes in healthy ruminants and swine in Northern Spain. BMC Veterinary Research, v.5, p.1-10, 2009. Avaliable from: <http:// bmcvetres.biomedcentral.com/articles/10.1186/1746-6148-5-2>. Accessed: May 22, 2016. doi: 10.1186/1746-6148-5-2.

EUROPEAN FOOD SAFETY AUTHORITY (EFSA). Scientific Report of EFSA. The European Union summary report on trends and sources of zoonoses, zoonotic agents and food-borne outbreaks in 2013. EFSA Journal, v.13, 162p., 2015. Avaliable from: $<$ https://www.efsa.europa.eu/en/efsajournal/pub/3991>. Accessed: May 22, 2016. doi: 10.2903/j.efsa.2015.3991

EUROPEAN FOOD SAFETY AUTHORITY (EFSA). Analysis of the baseline survey on the prevalence of Listeria monocytogenes in certain ready-to-eat foods in the European Union, 2010-2011. Part A: Listeria monocytogenes prevalence estimates. EFSA Journal, v.11, 75p. Listeriosis outbreaks and associated food vehicles, United States, 1998-2008, 2013. Avaliable from: <http:// www.efsa.europa.eu/en/efsajournal/pub/3241>. Accessed: May 22, 2016. doi: 10.2903/j.efsa.2013.3241

FAI, A.E.C. et al. Salmonella sp. e Listeria monocytogenes em presunto suíno comercializado em supermercados de Fortaleza (CE, Brasil): fator de risco para a saúde pública. Ciência \& Saúde Coletiva, v.16, p.657-662, 2011. Avaliable from: <http://www.scielo.br/ scielo.php?script $=$ sci_arttext\&pid $=\mathrm{S} 1413-81232011000200029>$. Accessed: May 22, 2016. doi: 10.1590/S1413-81232011000200029.

FARBER, J.M. et al. Changing regulation: Canada's new thinking on Listeria. Food Control, v.22, p.1506-1509, 2011. Avaliable from: $<$ http://www.sciencedirect.com/science/article/pii/ S0956713510002409>. Accessed: May 22, 2016. doi: 10.1016/j. foodcont.2010.07.019.

FOOD AND DRUG ADMINISTRATION (FDA). Bad bug book, foodborne pathogenic microorganisms and natural toxins. 2.ed. Silver Spring: U.S. Food and Drug Administration 2012. p.99-103. Avaliable from: <http://www.fda.gov/Food/ FoodborneIllnessContaminants/CausesOfIllnessBadBugBook/>. Accessed: May 22, 2016.

GANDHI, M.; CHIKINDAS, M.L. Listeria: a foodborne pathogen that knows how to survive. International Journal of Food Microbiology, v.113, p.1-15, 2007. Avaliable from: <http://www.sciencedirect.com/science/ article/pii/S01681605060043104>. Accessed: May 22, 2016. doi: 10.1016/j.ijfoodmicro.2006.07.008. 
HENRIQUES, A.R. et al. Assessing Listeria monocytogenes presence in Portuguese ready-to-eat meat processing industries based on hygienic and safety audit. Food Research International, v.63, p.81-88, 2014. Avaliable from: <http://www.sciencedirect.com/science/article/pii/ S096399691400204X>. Accessed: May 22, 2016. doi: 10.1016/j. foodres.2014.03.035.

HOF, H.; ROCOURT, J. Is any strain of Listeria monocytogenes detected in food a health risk? International Journal of Food Microbiology, v.16, p.173-182, 1992.

INSTITUTO BRASILEIRO DE GEOGRAFIA E ESTATÍSTICA (IBGE). População brasileira deve chegar ao máximo (228,4 milhões) em 2042. Avaliable from: $<$ http://cod.ibge.gov.br/232PG $>$. Accessed: May 22, 2016.

KRAMARENKO, T. et al. Listeria monocytogenes prevalence and serotype diversity in various foods. Food Control, v.30, p.2429, 2013. Avaliable from: <http://www.sciencedirect.com/science/ article/pii/S0956713512003799>. Accessed: May 22, 2016. doi: 10.1016/j.foodcont.2012.06.047.

LAMBERTZ, S.T. et al. Prevalence and level of Listeria monocytogenes in ready-to-eat foods in Sweden 2010. International Journal of Food Microbiology, v.160, p.24-31, 2012. Avaliable from: <http://www. sciencedirect.com/science/article/pii/S0168160512004837>. Accessed: May 22, 2016. doi:10.1016/j.ijfoodmicro.2012.09.010.

LEONG, D. et al. Monitoring occurrence and persistence of Listeria monocytogenes in foods and food processing environments in the Republic of Ireland. Frontiers in Microbiology, v.5, p.1-8, 2014. Avaliable from: $<$ http://journal.frontiersin.org/article/10.3389/fmicb.2014.00436/full >. Accessed: May 22, 2016. doi: 10.3389/fmicb.2014.00436.

MAMBER, S.W. Results of data analysis for the Listeria monocytogenes RLm risk-based sampling program calendar year 2008. USDA, September, 2010. Avaliable from: $<$ http://www. fsis.usda.gov/wps/portal/fsis/topics/data-collection-and-reports/ microbiology>. Accessed: May 22, 2016.

MARTÍN, B. et al. Diversity and distribution of Listeria monocytogenes in meat processing plants. Food Microbiology, v.44, p.119-127, 2014. Avaliable from: <http://www.sciencedirect. com/science/article/pii/S0740002014001208>. Accessed: May 22, 2016. doi: 10.1016/j.fm.2014.05.014.

MARTINS, I.S. et al. A cluster of Listeria monocytogenes infectious in hospitalized adults. American Journal of Infection Control, v.38, p.e31-e36, 2010. Avaliable from: <http://www. ajicjournal.org/article/S0196-6553(10)00449-9/abstract $>$. Accessed: May 22, 2016. doi: 10.1016/j.ajic.2010.02.014.

McLAUCHLIN, J. The identification of Listeria monocytogenes species. International Journal of Food Microbiology, v.38, p.77-81, 1997.

McLAUCHLIN, J. et al. Listeria monocytogenes and listeriosis: a review of hazard characterization for use in microbiological risk assessment of foods. International Journal of Food Microbiology, v.92, p.15-33, 2004. Avaliable from: <http://www.sciencedirect. com/science/article/pii/S016816050300326X>. Accessed: May 22, 2016. doi: 10.1016/S0168-1605(03)00326-X.

MENDONÇA, K.S. et al. Genetic relatedness among Listeria monocytogenes isolated in foods and food production chain in southern Rio Grande do Sul, Brazil. Food Control, v.28, p.171177, 2012. Avaliable from: <http://www.sciencedirect.com/science/
article/pii/S0956713512001764>. Accessed: May 22, 2016. doi: 10.1016/j.foodcont.2012.04.014

MUHTEREM-UYAR, M. et al. Environmental sampling for Listeria monocytogenes control in food processing facilities reveals three contamination scenarios. Food Control, v.51, p.94-107, 2015. Avaliable from: <http://www.sciencedirect.com/science/article/pii/ S0956713514006240>. Accessed: May 22, 2016. doi: 10.1016/j. foodcont.2014.10.042.

NOORDHOUT, C.M. et al. The global burden of listeriosis: a systematic review and meta-analysis. Lancet, v.16, p.1-10, 2014. Avaliable from: $<$ http://www.thelancet.com/journals/laninf/article/ PIIS1473-3099(14)70870-9/abstract $>$. Accessed: May 22, 2016. doi: 10.1016/S1473-3099(14)70870-9.

OKUTANI, A. et al. Overview of Listeria monocytogenes contamination in Japan. International Journal of Food Microbiology, v.93, p.131-140, 2004.

ORSI, R.H. et al. Listeria monocytogenes lineages: genomics, evolution, ecology and phenotypic characteristics. International Journal of Medical Microbiology, v.301, p.79-96, 2011. Avaliable from: $<$ http:// www.sciencedirect.com/science/article/pii/S1438422110000615>. Accessed: May 22, 2016. doi: 10.1016/j.ijmm.2010.05.002.

PÉREZ-TRALLERO, E. et al. Two outbreaks of Listeria monocytogenes infection, Northern Spain. Emerging Infectious Diseases, v.20, p.2155-2157, 2014. Avaliable from: <http://wwwnc. cdc.gov/eid/article/20/12/14-0993_article>. Accessed: May 22, 2016. doi: 10.3201/eid2012.140993.

PETTINATI, N.N. et al. Listeria monocytogenes in hot dog sausages obtained from groceries stores in the city of São Paulo - a comparative and retrospective analysis of human listeriosis isolates. Veterinaria e Zootecnia, v.13, p.182-191, 2006. Avaliable from: <http://www.fmvz. unesp.br/rvz/index.php/rvz/article/view/499>. Accessed: May 22, 2016.

REIS, C.M.F. et al. Antimicrobial susceptibilities of Listeria monocytogenes human strains isolated from 1970 to 2008 in Brazil. Revista da Sociedade Brasileira de Medicina Tropical, v.44, p.173-176, 2011. Avaliable from: <http://www.scielo.br/ scielo.php?script $=$ sci_arttext\&pid=S0037-86822011000200009>. Accessed: May22,2016. doi: 10.1590/S0037-86822011005000019.

RISTORI, C.A. et al. Prevalence and population of Listeria monocytogenes in meat retailed in São Paulo, Brazil. Foodborne Pathogens and Disease, v.11, p.969-973, 2014. Avaliable from: $<$ http://online.liebertpub.com/doi/abs/10.1089/fpd.2014.1809>. Accessed: May 22, 2016. doi: 10.1089/fpd.2014.1809.

ROSS, T. et al. Quantitative risk assessment of Listeria monocytogenes in ready-to-eat meats in Australia. International Journal of Food Microbiology, v.131, p.128-137, 2009. Avaliable from: <http:// www.sciencedirect.com/science/article/pii/S0168160509000981>. Accessed: May 22, 2016. doi: 10.1016/j.ijfoodmicro.2009.02.007.

ROSSI, L.P.R. et. Occurrence of Listeria spp. in Brazilian fresh sausage and control of Listeria monocytogenes using bacteriophage P100. Food Control, v.22, p.954-958, 2011. Avaliable from: $<$ http://www.sciencedirect.com/science/article/pii/ S0956713510004147>. Accessed: May 22, 2016. doi: 10.1016/j. foodcont.2010.12.001.

SALUDES, M. et al. Presence of Listeria monocytogenes in Chilean food matrices. Food Control, v.50, p.331-335, 2015. 
Avaliable from: $<$ http://www.sciencedirect.com/science/article/pii/ S0956713514004575>. Accessed: May 22, 2016. doi: 10.1016/j. foodcont.2014.08.008.

SCALLAN, E. et al. Foodborne illness acquired in the United States - Major pathogens. Emerging Infectious Diseases, v.17, p.7-15, 2011. Avaliable from: <http://www.ncbi.nlm.nih.gov/pmc/ articles/PMC3375761/pdf/09-1101p1_finalR.pdf $>$. Accessed: May 22, 2016. doi: 10.3201/eid1701.P11101.

SLUTSKER, L. et al. Foodborne diseases - Emerging pathogens and trends. Emerging Infectious Diseases, v.12, p.99-216, 1998. Avaliable from: $<$ http://www.ncbi.nlm.nih.gov/pubmed/9494839>. Accessed: May 22, 2016.

TIWERI, U. et al. Modelling the interaction of storage temperature, $\mathrm{pH}$ and water activity on the growth behaviour of Listeria monocytogenes in raw and pasteurized semi-soft rind washed milk cheese during storage following ripening. Food Control, v.42, p.248-256, 2014. Avaliable from: <http://www.sciencedirect. com/science/article/pii/S0956713514000644>. Accessed: May 22, 2016. doi: 10.1016/j.foodcont.2014.02.005.

TODD, E.C.E.; NOTERMANS, S. Surveillance of listeriosis and its causative pathogen, Listeria monocytogenes. Food Control, v.22, p.1484-1490, 2011. Avaliable from: <http://www.sciencedirect. com/science/article/pii/S0956713510002422>. Accessed: May 22, 2016. doi: 10.1016/j.foodcont.2010.07.021.

WORLD HEALTH ORGANIZATION/FOOD AND AGRICULTURE ORGANIZATION (WHO/FAO). Risk assessment of Listeria monocytogenes in ready-to-eat foods. ICMSF, 2004. Avaliable from: <ftp://ftp.fao.org/docrep/fao/010/ y5394e/y5394e.pdf>. Accessed: May 22, 2016. 